\title{
Mobile Authentication Service (MAS) Scheme and Public Participation in Eradicating Fake Drugs in South-East Nigeria
}

\author{
Chinonye Faith Chinedu-Okeke $(\mathrm{PhD})^{1}$, Nnanyelugo Okoro (Prof. $)^{2}$, Ijeoma Obi $(\mathrm{PhD})^{3}$ \\ ${ }^{1}$ Department of Mass Communication, Nnamdi Azikiwe University, Nigeria \\ ${ }^{2}$ Department of Mass Communication, University of Nigeria Nsukka, Nigeria \\ ${ }^{3}$ Department of Mass Communication, Chukwuemeka Odumegwu Ojukwu University, Nigeria \\ Correspondence Author*
}

\begin{abstract}
The issue of fake drugs is a global threat, especially in developing countries like Nigeria. Thus, National Agency for Food and Drug Administration and Control (NAFDAC), among other strategies, launched a Mobile Authentication Service (MAS) scheme that enables the public to authenticate drugs at the point of purchase using scratch codes and SMS. The study examined the level of public awareness, knowledge, and use of MAS in eradicating fake drugs in South-East Nigeria. The study adopted a mixed-methods research of Survey and Key Informant Interviews (KII). The data gathered from 400 respondents via a structured questionnaire were analyzed using descriptive and inferential analysis, while the transcripts from KII were thematically analysed. The analysed data reveals a low level of awareness, knowledge, and use of MAS among respondents, especially in rural areas. Some challenges faced by the respondents in the use of MAS include a low level of awareness and knowledge of MAS, poor network services, elitist nature of the campaign messages on MAS, and partial access to MAS among drug manufacturers. The data also reveal strategies towards enhancing the operations of MAS to ensure its efficiency in eradicating fake drugs in Nigeria. The study, therefore, concludes that the level of public awareness, knowledge, and use of MAS is relatively low, especially in rural areas. The study found that the use of MAS if enhanced is an efficient scheme in eradicating fake drugs in Nigeria.
\end{abstract}

Keywords: Mobile Authentication Service, Public Participation, Eradicate, Fake drugs.

\section{INTRODUCTION}

$\mathrm{T}$ he issue of fake drugs has been acknowledged as a significant public health problem that has assumed global dimensions, with more cases recorded in developing countries including Nigeria (Factsheet, 2013). The manufacturing, trading, and utilization of fake drugs in treating lifethreatening conditions has been documented as one of the causes of treatment failure, disabilities, high morbidity, mortality, and loss of public confidence in the Nigerian health sector (Joda et al., 2017).

Fake or counterfeit drug is a medicine or pharmaceutical item, which is deliberately and fraudulently produced and sold with the intent to deceptively represent its originality, authenticity, or effectiveness. Drug counterfeiting can apply to pharmaceutical products with the correct or wrong ingredients, insufficient active ingredients, fake packaging, or without active ingredients (Chika et al., 2011). Fake drugs are by their nature difficult to detect because they are often designed to appear identical to the genuine product and they often fail to properly treat the disease or condition for which they were intended to treat.

The high incidents of counterfeit drugs have ushered in recent years, the era of anti-counterfeiting regulatory agencies, which joins together in the fight against the menace (Akinyandenu, 2013). Thus, the National Agency for Food and Drug Administration and Control (NAFDAC) was established by the Federal Government of Nigeria in 1993 with the mandate to safeguard the health of the nation through the provision of effective regulation of the food, drug, and chemical sector of the economy.

Over the years, the agency has engaged different strategies like NAFDAC Registration Number, Truscan, Black Eye, and Radio Frequency Identification (RFID) in the fight against fake drugs in Nigeria (Ayodokun, 2016). However, due to some challenges faced by NAFDAC in the use of these technologies to fight against the production and sales of fake and substandard drugs, the agency on February 2, 2010, launched a Mobile Authentication Service (MAS) scheme that empowers the public in detecting counterfeit drugs using a communication medium (mobile phone) (NAFDAC News, 2013, p. 11). The scheme uses scratch codes and Short Messaging Service (SMS) to empower consumers to verify the authenticity of medicines at the point of purchase (NAFDAC News, 2013, p. 11).

Using the MAS scheme, the agency deployed the use of communication via the new media in authenticating drugs at the point of purchase, thereby enlisting the entire Nigerian public in the war against counterfeiting of drugs in Nigeria (Ebenezar, 2015). It became necessary therefore to assess the level of public awareness and the extent of their utilization of MAS to determine the effectiveness of the use of MAS in the fight against fake drugs in South-East Nigeria. 
The specific objectives of the study therefore include:

1. Ascertain the level of public awareness on the use of MAS in identifying fake drugs in South-East Nigeria.

2. Find out those factors affecting the level of public awareness on the use of MAS in identifying fake drugs in South-East Nigeria.

3. Assess the level of public utilization of MAS in detecting fake drugs in South-East Nigeria.

4. Examine those factors affecting the use of MAS in the fight against fake drugs in South-East Nigeria.

5. Appraise the public perception on the effectiveness of MAS in the fight against fake drugs in South-East Nigeria.

The findings of this study would be relevant to drug manufacturers, the general public, health care service providers, NAFDAC, health communication and pharmaceutical scholars, and the Nigerian government. The study will add to the body of literature in New Media, Health Communication, and Pharmaceutical studies, as well as open up what might be a new argument in MAS research. This study will also help to achieve SDG 3 that promotes good health and wellbeing.

\section{LITERATURE REVIEW AND THEORETICAL FRAMEWORK}

The issue of fake drugs has attracted the attention of various scholars across the globe. Thus, this study reviewed a significant number of literature related to this study.

\section{Conceptualizing Fake Drugs}

There is no universal definition of fake drug as every country has its own definition. According to World Health Organization (2017), counterfeit or fake drug is a medicine or pharmaceutical item, which is deliberately and fraudulently produced and sold with the intent to deceptively represent its originality, authenticity or effectiveness. Drug counterfeiting may apply to pharmaceutical products with the correct or wrong ingredients, insufficient active ingredients, fake packaging or without active ingredients (Ukaoha et al., 2015).

In view of the above definitions of fake drugs, there are different methods of drug faking such as tampering with original packages of large pack sized drugs, label swapping of two products manufactured by the same company, making the appearance of a counterfeit product look like original, labeling a low price drug products as the same with high price product label, passing off a company product for another product.

\section{Conceptualizing Mobile Authentication Service (MAS)}

The Mobile Authentication Service (MAS) of NAFDAC was launched on February 2, 2010, to engage the general public in identifying fake drugs the point of purchase through the help of technology from Sproxil (NAFDAC/Sproxil, 2015).

This communication technology enables a consumer to determine whether a drug is fake or genuine through a mobile phone by sending an SMS (a unique 12 or 13 digit number hidden under a scratch off panel that comes with the pack of every MAS-enabled drug product) to a service provider code number on the same product. The customer receives an SMS confirming whether the drug is genuine or fake. This process works anywhere in Nigeria where you can get mobile phone service on any of Nigeria's GSM networks: Airtel, MTN, Globacom and 9Mobile (former Etisalat).

According to NAFDAC's MAS Implementation Guide (2010, pp. 3-4), the roles of consumers and the general public in the use of MAS in the fight against fake drugs in Nigeria include:

1. To ensure that they scratch and text the PIN at the point of purchase

2. To ensure they text the right PIN to the right code

3. To ensure they buy drugs from only registered pharmacies and patent medicines outlets

4. To ensure they obtain and retain receipts of payment for items purchased in case there is an issue

5. To report all cases of counterfeit products to NAFDAC's anti-counterfeit desk in Pharmacovigilance and Post Marketing Surveillance Directorate

More so, the roles of the Association of Community Pharmacist of Nigeria (ACPN) in the use of MAS in the fight against fake drugs in Nigeria include:

1. Creating awareness amongst the patrons of the shops and the general public on the need to activate the PIN code on the products through scratching and texting.

2. Pharmacists are to authenticate the outer packs of medicines before the consumer will scratch and text from the primary packaging to authenticate the purchased product. (NAFDAC's MAS Implementation Guide, 2010, p. 4).

\section{Public Participation: An Overview}

Public participation can be described as a deliberative process by which interested or affected citizens, civil society organisations, and government actors are involved in policymaking before a political decision is taken. In other words, public participation can be any process that directly engages the public in decision-making and gives full consideration to public input in making that decision (Mdunyelwa, 2008 cited in Moseti, 2010). Public participation aims at bridging the gap between the government, civil society, private sector and the general public, building a common understanding about the local situation, priorities and programmes. Thus, public participation encourages openness, accountability and transparency, and is therefore at the heart of inclusive and better decision-making (United States Environmental Protection Agency, 2021). In this contemporary society, the new media has become an increasingly prominent tool for NAFDAC in enagaging the public for a collaborative fight against fake drugs in Nigeria. 


\section{THEORETICAL FRAMEWORK}

Uses and Gratifications Theory, which was propounded in 1970 by Blumler and Katz, was adopted for this study to elucidate why and how people actively seek out specific media to satisfy specific needs (McQuail, 2010). The theory is an approach towards understanding why, how and at what rate people adopt new idea or seek out specific media to satisfy specific needs.

Employing uses and gratification theory therefore provides useful explanation and evaluation to the inherent effective uses and gratifications which NAFDAC and the general public derive from the adoption of new media especially in satisfying their informational needs towards eradicating fake drugs in Nigeria.

\section{DATA AND METHODS}

The study adopted a Sequential mixed methods (descriptive design), combining survey method and in-depth interview. The research methods were selected to complement each other, which "reflect an attempt to secure an in-depth understanding of the phenomenon in question (Denzin \& Lincoln, 2003: 8).

Using the survey method, the study also examined the demographic characteristics of respondents as well as other factors affecting the level of public awareness and use of MAS in identifying fake drugs in South-East Nigeria. The survey method was also used to examine the public perception of the effectiveness of the use of Mobile Authentication Service (MAS) in identifying fake in Nigeria.

On the other hand, in-depth interview was used to evaluate the public perception on the effectiveness of the use of Mobile Authentication Service (MAS) in identifying fake drugs in South-East Nigeria. Using in-depth interview, the study also examined the demographic characteristics of respondents as well as other factors affecting the level of public awareness and use of MAS in identifying fake drugs in South-East Nigeria. In-depth interview is useful when a researcher want detailed information about a person's thoughts and behaviours or want to explore new issues comprehensively (Dudu \& Danjuma, 2016).

All the people in the five states (Abia, Anambra, Ebonyi, Enugu and Imo states) that make up the South-East Nigeria forms the population for the study. The population data as at 2006 was about 16,381,729 (National Population Commission, 2006). According to NPC Chairman, Eze Duruiheoma (2018), the estimated Nigeria Population could be calculated based on annual population growth of 3.2 per cent, spanning from 2006 to Date (2018). Thus, an estimated population of the five states in South-East Nigeria was calculated using a $3.2 \%$ continuous annual growth rate from 2006 to 2018 (which is 12 years), amounting to about $22,672,321$
Table one: States Distribution

\begin{tabular}{|c|c|c|c|}
\hline S/N & States & $\begin{array}{c}\text { Population as at } \\
2006\end{array}$ & $\begin{array}{c}\text { Estimated Population as } \\
\text { at } 2018\end{array}$ \\
\hline 1. & Abia & $2,833,999$ & $3,922,255$ \\
\hline 2. & $\begin{array}{c}\text { Anambr } \\
\text { a }\end{array}$ & $4,182,032$ & $5,787,932$ \\
\hline 3. & Ebonyi & $2,173,501$ & $3,008,125$ \\
\hline 4. & Enugu & $3,257,298$ & $4,508,106$ \\
\hline 5. & Imo & $3,934,899$ & $5,445,903$ \\
\hline & TOTAL & $16,381,729$ & $22,672,321$ \\
\hline
\end{tabular}

The sample size for this study will be determined by looking at the different sample sizes worked out using Creative System Research Calculator as well as Taro Yamane's formula for determining sample size.

Using the Creative System Research Calculator with a confidence level of $95 \%$ and a confidence interval of 5 to calculate the sample size, a total of 384 would be the sample size.

Considering the suggestion by Stacks and Hocking (1999, p. 217) that, "the larger the sample, the more representative of the population the sample will be and the smaller your error will be", a sample of 400 was decided upon.

On the other hand, Guest, Arwen and Johnson (2006) suggest that saturation of meta-themes can usually be achieved with 12 interviews, but 20 interviews was decided upon to fully develop patterns, concepts, categories, properties, and dimensions of the given phenomena.

Multistage sampling procedure was adopted for the study. In selecting the sample for the in-depth interview, the study adopted a theoretical sampling procedure that enables the researcher to choose participants who have experience or who are experiencing the phenomenon under study. By so doing, the researcher has chosen "experts" in the phenomenon who are able to provide the best data (Corbin \& Strauss, 1998 as cited in Thomson, 2011). Thus, two pharmacists were randomly selected to represent each of the 10 selected Local Government Areas under study. Pharmacists were chosen because, majority of the medicines consumed by the public were purchased in retails and only the pharmacists have access to the packets of those medicines, thus the scratching of the panel lies in their hands.

In each study location, the customers in pharmacy shops as well as patent medicine stores were targeted. After the initial introduction/consent seeking and based on the mood of the customer (pharmacists) in question, there was a brief administration of the questionnaire with a further request if such a person shows interest to participate in further discussions about the subject. In this way, his/her contact details were collected for further interaction via in-depth interview.

For analyzing the quantitative data, the Statistical Package for Social Sciences (SPSS) version 21 was used. In analyzing the 
transcripts from in-depth interviews, the Braun and Clarke's thematic analysis was used to uncover themes and trends relating to the objectives of the study. Excerpts of the transcripts will be used to complement the quantitative results where possible.

\section{RESULTS}

The questionnaire was administered to 400 respondents $(10$ respondents from each of the 40 communities representing 10 L.G.As selected for this study). Three Hundred and Ninety Eight (398) out of 400 copies of the questionnaire administered to the respondents were returned. Therefore, the total (398) copies of the questionnaire returned represents 99 per cent return rate.

\section{Level of Public Awareness on the Use of MAS in Identifying} Fake Drugs

In order to answer research question one that seeks to find out the level of public awareness on NAFDAC's Mobile Authentication Service, respondents were asked a number of questions and the data gathered were stated in tables 2, 3 and 4 below.

Table two: Public awareness on the use of MAS in identifying fake drugs

\begin{tabular}{|c|c|c|}
\hline $\begin{array}{c}\text { Public Awareness of } \\
\text { MAS }\end{array}$ & Frequency & $\begin{array}{c}\text { Percentage } \\
(\%)\end{array}$ \\
\hline Yes & 231 & $58 \%$ \\
\hline No & 167 & $42 \%$ \\
\hline Total & 398 & $100 \%$ \\
\hline
\end{tabular}

The data in table 2 reveals that 58 per cent of the respondents are aware of the use of MAS in detecting fake drugs, while 42 per cent of the respondents are not aware of the use of MAS in identifying fake drugs in South East Nigeria. The analyzed data therefore suggest that majority of the respondents are aware of the use of MAS in identifying fake drugs in Nigeria.

Table three: Respondents' perception on the nature of campaign messages on MAS

\begin{tabular}{|c|c|c|}
\hline $\begin{array}{c}\text { Level of exposure to campaign } \\
\text { messages on MAS }\end{array}$ & Frequency & Per cent age \\
\hline Informative & 183 & $46 \%$ \\
\hline Educative & 203 & $51 \%$ \\
\hline Entertaining & 0 & $0 \%$ \\
\hline Influencing & 8 & $2 \%$ \\
\hline Persuasive & 4 & $1 \%$ \\
\hline Total & 398 & $100 \%$ \\
\hline
\end{tabular}

The data in table 3 shows that 51 percent of the respondents perceive the campaigns on MAS to be educative in nature, 46 percent of the respondents perceived it to be informative in nature, 2 per cent of the respondents perceived it to be influencing in nature, while only 1 per cent of the respondents perceived campaign messages on MAS to be persuasive in nature. The analyzed data therefore suggests that the majority of the respondents perceived campaign messages on MAS to be educative in nature.

Table four: Respondents' level of knowledge on the use of MAS in identifying fake drugs

\begin{tabular}{|c|c|c|}
\hline $\begin{array}{c}\text { Level of knowledge on the use } \\
\text { of MAS }\end{array}$ & Frequency & Per cent age \\
\hline Highly informed & 96 & $24 \%$ \\
\hline Partially informed & 231 & $58 \%$ \\
\hline Still not informed & 71 & $18 \%$ \\
\hline Total & 398 & $100 \%$ \\
\hline
\end{tabular}

The data in table 4 shows that 58 per cent of the respondents are partially informed on the use of MAS in identifying fake drugs in South East Nigeria, 24 per cent of the respondents are highly informed, while 18 per cent of the respondents are still not informed on the use of MAS in identifying fake drugs in South East Nigeria.

Factors Affecting the Level of Public Awareness on the Use of MAS in Identifying Fake Drugs

In order to answer research question two that seeks to find out factors affecting the level of public awareness on the use of MAS in identifying fake drugs in South East Nigeria, the data gathered were stated in table 5 below.

Table five: Factors affecting the level of public awareness on the use of MAS

\begin{tabular}{|c|c|c|}
\hline $\begin{array}{c}\text { Factors affecting the level } \\
\text { of public awareness on the } \\
\text { use of MAS }\end{array}$ & & Percentage $(\%)$ \\
\hline \multicolumn{3}{|c|}{$\begin{array}{c}\text { Sex (Gender) influences your receiving and understanding of the } \\
\text { campaign message(s) on MAS }\end{array}$} \\
\hline Yes & 127 & $32 \%$ \\
\hline No & 271 & $68 \%$ \\
\hline Total & 398 & $100 \%$ \\
\hline \multicolumn{3}{|c|}{$\begin{array}{l}\text { Level of education influences the receiving and understanding of } \\
\text { campaign message(s) on MAS }\end{array}$} \\
\hline Yes & 378 & $95 \%$ \\
\hline No & 20 & $5 \%$ \\
\hline Total & 398 & $100 \%$ \\
\hline \multicolumn{3}{|c|}{$\begin{array}{l}\text { Type of occupation influences the receiving and understanding of } \\
\text { campaign message(s) on MAS }\end{array}$} \\
\hline Yes & 40 & $10 \%$ \\
\hline No & 358 & $90 \%$ \\
\hline Total & 398 & $100 \%$ \\
\hline \multicolumn{3}{|c|}{$\begin{array}{c}\text { Marital status influences the receiving and understanding of } \\
\text { campaign message(s) on MAS }\end{array}$} \\
\hline Yes & 28 & $7 \%$ \\
\hline No & 370 & $93 \%$ \\
\hline Total & 398 & $100 \%$ \\
\hline \multicolumn{3}{|c|}{$\begin{array}{l}\text { Residential location influences the receiving and understanding of } \\
\text { campaign message(s) on MAS }\end{array}$} \\
\hline Yes & 346 & $87 \%$ \\
\hline No & 52 & $13 \%$ \\
\hline
\end{tabular}




\begin{tabular}{|c|c|c|}
\hline Total & 398 & $100 \%$ \\
\hline $\begin{array}{c}\text { Cultural/religious belief influences the receiving/understanding of } \\
\text { campaign message(s) on MAS }\end{array}$ \\
\hline Yes & 76 & $19 \%$ \\
\hline No & 322 & $81 \%$ \\
\hline Total & 398 & $100 \%$ \\
\hline
\end{tabular}

The data in table 5 shows that 68 per cent of the respondent do not believe that sex (gender) influences them in receiving and understanding of the campaign message(s) on MAS, while 32 per cent of the respondent believed that being a male or female influences them in receiving and understanding of the campaign message(s) on MAS. The analysed data therefore suggest that majority of the respondents do not believe that sex (gender) influences them in receiving and understanding of the campaign message(s) on MAS.

The data in table 5 also reveals that 95 per cent of the respondents believed that their level of education influences them in receiving and understanding of campaign message(s) on MAS, while only 5 per cent of the entire respondents do not believe that their level of education influences them in receiving and understanding of campaign message(s) on MAS.

The data in table 5 also shows that 90 per cent of the respondents believed that their type of occupation does not influence them in receiving and understanding of campaign message(s) on MAS, while 10 per cent of the entire respondents believed that their type of occupation influences them in receiving and understanding of campaign message(s) on MAS.

The data in table 5 also indicates that 93 per cent of the respondents believed that their marital status does not influence them in receiving and understanding of campaign message(s) on MAS, while 7 per cent of the entire respondents believed that their marital status influences them in receiving and understanding of campaign message(s) on MAS.

The data in table 5 also shows that 87 per cent of the respondents believed that their place of residence (urban or rural) influences them in receiving and understanding of campaign message(s) on MAS, while only 13 per cent of the respondents do not believe that their place of residence influences them in receiving and understanding of campaign message(s) on MAS. The analyzed data therefore suggest that majority of the respondents believe that their place of residence influences them in receiving and understanding of campaign message(s) on MAS, may be, due to the elitist nature of the campaign messages on MAS.

The data in table 5 also shows that 81 per cent of the respondents believed that their cultural or religious belief does not influence them in receiving and understanding of campaign message(s) on MAS, while 19 per cent of the respondents believed that their cultural or religious belief influences them in receiving and understanding of campaign message(s) on MAS.

\section{Respondents' Level of Use of MAS in Identifying Fake Drugs}

In order to answer research question three that seeks to find out the level of public use of NAFDAC's Mobile Authentication Service in detecting fake drugs in SouthEastern Nigeria, the data gathered were stated in table 6 below.

Table six: Respondents' Level of Utilization of MAS

\begin{tabular}{|c|c|c|}
\hline Frequency of Use of MAS & Frequency & Percentage \\
\hline Regularly & 48 & $12 \%$ \\
\hline Occasionally & 64 & $16 \%$ \\
\hline Not at all & 231 & $58 \%$ \\
\hline Don't Know & 55 & $14 \%$ \\
\hline Total & 398 & $100 \%$ \\
\hline
\end{tabular}

In showing respondents' level of use of MAS in identifying fake drugs, the data in table 6 shows that the majority (58\%) of the respondents don't use MAS at all, followed by 16 per cent of the respondents who used it occasionally, to 14 per cent of the respondents who do not know if they use MAS or not. Surprisingly, only 12 per cent of the entire respondents use MAS regularly.

Factors affecting the use of MAS in identifying fake drugs in South East Nigeria

In order to answer research question four that seeks to examine those factors affecting the use of Mobile Authentication Service (MAS) in identifying fake drugs in South East Nigeria, the data gathered were stated in table 7 below.

Table seven: Respondents' Challenges on the Use of MAS in Identifying Fake Drugs

\begin{tabular}{|c|c|c|}
\hline Greatest Challenge in the use of MAS & Frequency & $\begin{array}{c}\text { Percentage } \\
(\%)\end{array}$ \\
\hline No time to use it & 44 & $11 \%$ \\
\hline The service (network) is very poor & 68 & $17 \%$ \\
\hline $\begin{array}{c}\text { The Response from NAFDAC is most } \\
\text { times delayed }\end{array}$ & 191 & $48 \%$ \\
\hline Do not know how to use it at all & 35 & $9 \%$ \\
\hline $\begin{array}{c}\text { I do not have full information on how } \\
\text { to use it }\end{array}$ & 16 & $4 \%$ \\
\hline $\begin{array}{c}\text { Most drugs do not carry the MAS } \\
\text { application }\end{array}$ & 24 & $6 \%$ \\
\hline $\begin{array}{c}\text { Most customers buy drugs in retail } \\
\text { which prevents them from seeing the } \\
\text { package for authentication }\end{array}$ & 20 & $5 \%$ \\
\hline Total & 398 & $100 \%$ \\
\hline
\end{tabular}

The data in table 7 revealed the challenges faced by the public in the use of MAS in identifying fake drugs in South-East Nigeria. 48 per cent of the respondents believed the response from NAFDAC are most times delayed, 19 per cent of the respondents believe their network services are very poor, 11 
per cent of the respondents do not have time to use the MAS, 9 per cent of the respondents do not know how to use it, 6 per cent of the respondents said that most drugs do not carry the MAS application, 5 per cent of the respondents said that most customers buy drugs in retail which prevents them from seeing the packets for authentication, while 4 per cent of the respondents said they do not have full information on how to use MAS to identify fake drugs.

In order to find out the demographic characteristics of the respondents, if any, that affects their use of MAS in identifying fake drugs in South East Nigeria, the data gathered were stated in table 8 below.

Table eight: The most influential Demographic Characteristics that influence the respondents' adoption or rejection of MAS in identifying fake drugs in South-East Nigeria

\begin{tabular}{|c|c|c|}
\hline Demographic Characteristics & Frequency & Percentage (\%) \\
\hline Sex (Gender) & 8 & $2 \%$ \\
\hline Educational level & 207 & $52 \%$ \\
\hline Occupation & 24 & $6 \%$ \\
\hline Marital Status & 4 & $1 \%$ \\
\hline Residential location (urban or rural) & 151 & $38 \%$ \\
\hline Cultural/Religious background & 4 & $1 \%$ \\
\hline Total & 398 & $100 \%$ \\
\hline
\end{tabular}

The data in table 8 shows that 52 per cent of the respondents believed their level of education determines their adoption or rejection of MAS, 38 per cent of the respondents believed their residential location (rural/urban) determines their adoption or rejection of MAS, 6 per cent of the respondents believed their occupation determines their adoption or rejection of MAS, 1 per cent of the respondents believed their marital status determines their adoption or rejection of the use of MAS in identifying fake drugs, while another 1 per cent of the respondents believed their cultural or religious belief influences their use of MAS in identifying fake drugs in South-East Nigeria.

Respondents' Perception on the Effectiveness of Mobile Authentication Service (MAS) in Identifying Fake Drugs in South-East Nigeria

In order to answer research question five that seeks to find out the public perception on the effectiveness of Mobile Authentication Service (MAS) in identifying fake drugs in South-Eastern Nigeria, respondents were asked a number of questions and the data gathered were stated in tables 9, 10, 11 and 12 below.

Table nine: Respondents' perception on the effectiveness of the use of MAS in identifying fake Drugs

\begin{tabular}{|c|c|c|}
\hline $\begin{array}{c}\text { If Yes, how effective is the use of } \\
\text { MAS in the fight against fake drugs in } \\
\text { Nigeria? }\end{array}$ & Frequency & $\begin{array}{c}\text { Percentage } \\
(\%)\end{array}$ \\
\hline Very effective & 151 & $38 \%$ \\
\hline Slightly effective & 211 & $53 \%$ \\
\hline
\end{tabular}

\begin{tabular}{|c|c|c|}
\hline Don't know & 36 & $9 \%$ \\
\hline Total & 398 & $100 \%$ \\
\hline
\end{tabular}

The data in table 9 shows that 53 per cent of the respondents believed the use of MAS in identifying fake drugs is slightly effective, 38 per cent of the respondents believed the use of MAS is very effective, while 9 per cent of the respondents do not know how to rate the level of effectiveness of the use of MAS in identifying fake drugs in South East Nigeria.

\section{Qualitative Analysis}

In order to find out the demographic characteristics of respondents and other factors affecting the level of public awareness and use of MAS as well as evaluate the public perception on the effectiveness of the use of MAS in identifying fake drugs in South-East Nigeria, the data gathered from 20 interviews via a 5 -item interview guide were presented and analysed below.

Table 10: Respondents' Challenges on the Use of MAS in Identifying Fake Drugs

\begin{tabular}{|c|c|c|}
\hline Greatest Challenge in the Use of MAS & Frequency & $\begin{array}{c}\text { Percentag } \\
\text { e (\%) }\end{array}$ \\
\hline No time to use it & 3 & $6 \%$ \\
\hline Poor network services & 3 & $7 \%$ \\
\hline Delayed responses from NAFDAC & 19 & $40 \%$ \\
\hline Low level of information on how to use it & 4 & $9 \%$ \\
\hline $\begin{array}{c}\text { Most drugs do not carry the MAS } \\
\text { application }\end{array}$ & 6 & $12 \%$ \\
\hline $\begin{array}{c}\text { Most customers buy drugs in retail which } \\
\text { prevents them from seeing the package for } \\
\text { authentication }\end{array}$ & 7 & $15 \%$ \\
\hline $\begin{array}{c}\text { Poor electricity power supply to charge } \\
\text { their mobile phones }\end{array}$ & 1 & $1 \%$ \\
\hline $\begin{array}{c}\text { the elitist nature (choice of language and } \\
\text { media) of NAFDAC's campaign messages } \\
\text { on the use of MAS prevents the } \\
\text { respondents from understanding how to } \\
\text { use MAS in identifying fake }\end{array}$ & 5 & $10 \%$ \\
\hline \begin{tabular}{c} 
Total \\
\hline
\end{tabular} & 48 & $100 \%$ \\
\hline
\end{tabular}

Source: Quantified data from In-depth Interviews

The data in table 10 revealed the challenges faced by the public in the use of MAS in identifying fake drugs in SouthEast Nigeria. 40 per cent of the respondents believed the response from NAFDAC are most times delayed, 15 per cent of the respondents believed most customers buy drugs in retail which prevents them from seeing the package for authentication, 12 per cent of the respondents believe most drugs do not carry the MAS application, 10 per cent of the respondents believed the elitist nature (choice of language and media) of NAFDAC's campaign messages on the use of MAS prevents them from understanding and utilizing MAS in identifying fake, 9 per cent of the respondents said they did not know how to use it due to low level of information on MAS usage, 7 per cent of the respondents said they experienced poor network services, 6 per cent of the 
respondents said they have no time to use it, while 1 per cent of the respondents said that poor electricity supply to charge their phones affects their level of awareness and use of MAS.

Respondents' Perception on the effectiveness of MAS in identifying fake drugs in South-East Nigeria

In collaboration with the quantitative data stated above that the use of MAS if improved is an effective strategy in identifying fake drugs, respondents' suggestions on how to enhance the use of MAS were quantified, presented and analyzed below.

Table 11: Respondents' Suggestions on how to improve on the Use of MAS

\begin{tabular}{|c|c|c|}
\hline $\begin{array}{c}\text { Suggestions on how to improve on the } \\
\text { Use of MAS }\end{array}$ & Frequency & $\begin{array}{c}\text { Percentage } \\
(\%)\end{array}$ \\
\hline $\begin{array}{c}\text { The need to create more awareness on } \\
\text { the use of MAS }\end{array}$ & 21 & $35 \%$ \\
\hline $\begin{array}{c}\text { NAFDAC's use of multi-media in } \\
\text { creating more awareness on the use of } \\
\text { MAS }\end{array}$ & 15 & $26 \%$ \\
\hline $\begin{array}{c}\text { A good network service to ensure } \\
\text { immediate response from NAFDAC as } \\
\text { targeted }\end{array}$ & 13 & $22 \%$ \\
\hline $\begin{array}{c}\text { Reducing the number of retailed drugs } \\
\text { which are counted and providing mini } \\
\text { packets with MAS number. }\end{array}$ & 6 & $10 \%$ \\
\hline $\begin{array}{c}\text { Manufacturers' charges to use MAS } \\
\text { should be subsidized in order to carry all } \\
\text { drug manufacturers along. }\end{array}$ & 2 & $4 \%$ \\
\hline $\begin{array}{c}\text { Government should address the problem } \\
\text { of poor infrastructure especially in the } \\
\text { area of poor electricity supply. }\end{array}$ & 2 & $3 \%$ \\
\hline Total & 59 & $100 \%$ \\
\hline
\end{tabular}

Source: Quantified data from In-depth Interviews

The data in table 11 shows that 35 per cent of the respondents suggest the need to create more awareness on the use of MAS, 26 per cent of the respondents suggest NAFDAC's use of multi-media in creating more awareness on the use of MAS, 22 per cent of the respondents suggest the use of a good network service to ensure immediate response from NAFDAC as targeted, 10 per cent of the respondents suggest that drug manufacturers reduce the number of counted drugs by providing mini packets with MAS number, 4 per cent of the respondents suggest that drug manufacturers' charges to use MAS should be subsidized in order to carry all drug manufacturers along, while 3 per cent of the respondents suggest that government should address the problem of poor infrastructure especially in the area of poor electricity supply to enable them charge their mobile phones.

\section{DISCUSSION}

In answering research question one, the analyzed data in tables 2, 3 and 4 stated it clearly that the level of public awareness on the use of MAS in the fight against fake drugs is relatively low. Thus, revealing the assertion by WHO (2002) that the business of fake drugs and drugs counterfeiting only come to limelight in the events of deaths.
In answering research question two, the analyzed data in table 5 shows that educational level of the public, location of the residents (rural or urban) and sex influence their level of awareness on the use of MAS in identifying fake drugs in South-East Nigeria. The data in table 5 also reveals that 95 per cent of the respondents believed their level of education influences them in receiving and understanding of campaign message(s) on MAS, may be, due to the elitist nature of the campaign messages on MAS. The data in table 5 also shows that 87 per cent of the respondents believed that their place of residence (urban or rural) influences them in receiving and understanding of campaign message(s) on MAS.

In answering research question three, the analyzed data in table 6 shows that, there is a relatively low level of public utilization of MAS in the studied locations. This low level of awareness and low level of utilization of MAS in identifying fake drugs was recorded more in the rural areas. The findings therefore conform to the findings of Eronmhonsele (2015) that the level of awareness and use of MAS in identifying fake drugs is low in Edo State, Nigeria.

In answering research question four that seeks to find out those demographic characteristics of the respondents that influences their awareness and use of MAS, the analyzed data in table 8 shows that respondents' level of awareness and use of MAS has been influenced by some of their demographic characteristics. The analyzed data therefore shows that majority of the respondents believed their educational level and residential location (urban/rural) influence their level of awareness and use of MAS in identifying fake drugs in SouthEast Nigeria.

More so, the analyzed data in tables 7 and 10 (interview excerpts) show the respondents' challenges in the use of MAS. Some of the challenges include: poor network services leading to untimely response to the text at the point of purchase, which more or less defeat the purpose of the MAS. Another revelation from the excerpts is the issue of level of awareness on the use of MAS in identifying fake drugs. The study found that the awareness campaign of the service is mainly for the urban populace where mass media are readily available, which is not a regular source of information to rural dwellers. Consequently, most rural dwellers are cut off from the knowledge and usage of MAS even when some of them may have desire to use the service. Again, the scratch off panel is not in all drugs especially retailed/dispensed drugs in medicine stores. Even if one is knowledgeable about the usage, authenticating such drugs becomes an extremely difficult task. Also, we have attitudinal issue with most consumers who are always in haste and considered the use of MAS as a useless expenditure of time.

In answering research question five, the analyzed data in tables 9 and 11 (interview excerpts) indicate that the respondents believe the use of MAS would be an effective strategy in identifying fake drugs if the following suggestions are put into consideration: the use of multi-media approach 
(strategic communication) by the NAFDAC in creating awareness on the use of MAS in identifying fake drugs. They also suggested the use of good/improved network services so as to ensure immediate response from NAFDAC as targeted. In the area of retailed drugs as well as other drugs excluded from the service, the respondents suggested that NAFDAC should make it a policy to make sure that the companies develop strategies to key into MAS like reducing the number of retailed/dispensed drugs and providing mini packets with MAS number. Again, Charges on the part of manufacturers to use MAS should be subsidized as low as possible in order to carry all drug manufacturers along.

However, it is noteworthy that ensuring the effectiveness of the use of MAS in the fight against fake drugs conforms to the assumption of the Uses and Gratifications theory that people seek out specific media to satisfy specific needs.

\section{CONCLUSION}

In view of the findings of this research work, this study concludes that the level of public awareness of MAS is relatively low, especially in the rural communities. The major factors affecting the level of public awareness on the use of MAS in identifying fake drugs include: educational level of the respondents, residential locations as well as the sex of the respondents. The low level of awareness on the use of MAS in identifying fake drugs has in turn led to low utilization of the service both in urban and rural locations, even though there seems to be a higher incidence of the utilization of MAS in urban centres than the rural communities.

Some factors affecting the use of MAS in identifying fake drugs include: low level of awareness on the use of MAS, elitist nature of NAFDAC's awareness campaigns, which has limited the reach of the service to mostly urban localities, with very little effects in rural communities, poor network services, untimely response to text which more or less defeat the purpose of the MAS, difficulties in authenticating dispensed drugs, etc. The use of MAS, if improved, is an effective and best strategy in identifying fake drugs in South-Eastern Nigeria, because it puts the power of detecting fake drugs into the hands of the public/consumers, thus making the strategy a participatory strategy, where all hands must be on desk towards eradicating fake drugs in Nigeria.

The study will add to the body of literature in New Media, Health Communication and Pharmaceutical studies. The findings of this research might engender new strategies on how to improve on the operations and effectiveness of MAS in the fight against fake drugs in South-East Nigeria.

\section{REFERENCES}

[1] Akinyandenu, O. (2013). Counterfeit drugs in Nigeria: A threat to public health. African Journal of Pharmacy and Pharmacology, 7(36), 2571-2576.

[2] Ayodokun, O. J. (2016). The Use of Mobile Phone to check for the Authenticity of Pharmaceutical Products in Nigeria a case study of Mobile Authentication Service (MAS). Retrieved on $22^{\text {nd }}$ July 2017 from http://www.ifra-nigeria.org.
[3] Biztechafrica.com (2013). Sproxil, IBM partner to fight counterfeit drugs. Retrieved 30th March from http://www.biztechafrica.com/article/sproxil-ibm-partner-to-fightcounterfeir-drugs/2739.

[4] Chika, A., Bello, S. O., Jimoh, A. O., \& Umar, M. T. (2011). The menace of fake drugs: consequences, causes and possible solutions. Research Journal of Medical Sciences, 5 (5), 257-261.

[5] Denzin, N. K., \& Lincoln, Y. S. (2003). Collecting and interpreting qualitative materials. Sage. Thousand Oaks, Calif.,

[6] Dudu, J.E., \& Danjuma, M.N. (2016). Awareness and Use of the National Agency for Food and Drug Administration and Control's Mobile Authentication Service For Detecting Counterfeit Drugs In Nigeria. IOSR Journal of Humanities and Social Science (IOSRJHSS), 21 (2, 3), 21-31.

[7] Erhun, W.O., Erhun, M.O., \& Babalola, O.O. (2004). Drug regulation and control in Nigeria: The challenge of counterfeit drugs. Journal of Health and Population in Developing Countries, 4 (2), 23-34.

[8] Eronmhonsele, J.I. (2015). Detecting Counterfeit Drugs through Mobile Authentication Service (MAS): Users' Challenges in Edo South Senatorial District. International Journal of Pharmaceutical Science Invention, 4 (9), 13 -18.

[9] Factsheet (2013). Combating counterfeiting of medical products and similar crimes Factsheet medicrime convention. Retrieved on 30th March 2017 from www.coe.int/medicrime.

[10] Guest, G., Arwen Bunce, \& Johnson, L. (2006). How Many Interviews Are Enough?: An Experiment with Data Saturation and Variability. Field Methods, 18(1), 59-82. doi:10.1177/1525822X05279903

[11] Joda AE, Amadi C, Adebayo OI, Maji YI, Uchem C, Olih H. Fake drugs: A survey of healthcare providers in Lagos State, Nigeria. Niger J Basic Clin Sci 2017;14:137-42

[12] McCullen, N. J. (2013). Multiparameter Models of Innovation Diffusion on Complex Networks. SIAM Journal on Applied Dynamical Systems, 12 (1), 515-532.

[13] McQuail, D. (2010). Mass Communication Theory: An Introduction. London: Sage Publications.

[14] Moseti, Y. (2010), Public participation for sustainable development in local cities. 46th ISOCARP Congress 2010, Kenya.

[15] NAFDAC's MAS Implementation Guide (2010). The National Agency for Food and Drug Administration and Control (NAFDAC) Mobile Authentication Service Scheme Guidelines for the Procurement and Management of the NAFDAC Mobile Authentication Service (MAS) Scheme. (Accessed May 5, 2017)

[16] NAFDAC News (2013). Issue 4.

[17] NAFDAC/Sproxil (2015). Cares Frequently asked questions on national anti-counterfeit mobile authentication service (MAS) Available http://sproxil.com/docs/NAFDAC_Sproxil_BIOFEM_MAS_FAQ. pdf (Accessed May 5, 2017)

[18] National Population Commission (2006). Nigerian Census

[19] Rogers, E. (2003). Diffusion of Innovation Theory. New York: Free Press.

[20] Stack, D.W., \& Hocking, J.E. (1999). Communication Research. New York: Addison-Wesley

[21] Thomson, S.B. (2011). Sample Size and Grounded Theory. JOAAG, 5 (1), 45-52. Available at: http://www.joaag.com/uploads/5_1_Research_Note_1_Thomson. pdf

[22] Ukaoha, K. C., Dim, C. N., Daodu, S. S., \& Odikayor-Ogbomo, F. I. (2015). Towards A Mobile Drugs Authentication System for Nigerian Users. Computing, Information Systems, Development Informatics \& Allied Research Journal, 6 (1), 35- 40.

[23] United States Environmental Protection Agency (2021). Public Participation Guide: Introduction to Public Participation.https://www.epa.gov/internationalcooperation/public-participation-guide-introduction-publicparticipation

[24] Visser, P. S., Krosnick, J. A., Marquette, J., \& Curtin, M. (2000). Improving election forecasting: Allocation of undecided 
respondents, identification of likely voters, and response order effects. In P. Lavrakas \& M. Traugott (Eds.), Election polls, the news media, and democracy. New York, NY: Chatham House.

[25] World Health Organization (2017). A study on the public health and socioeconomic impact of substandard and falsified medical products.
https://www.who.int/medicines/regulation/ssffc/publications/Layo ut-SEstudy-WEB.pdf

[26] WHO (2007). Good governance for medicines. Curbing corruption in medicines regulation and supply. www.who.int/medicines/policy/goodgovernance/home/en/index.ht $\mathrm{ml}$ 